\begin{tabular}{|c|c|}
\hline \multirow{3}{*}{ 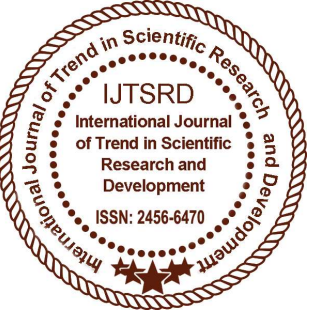 } & $\begin{array}{l}\text { International Journal of Trend in Scientific } \\
\text { Research and Development (IJTSRD) }\end{array}$ \\
\hline & International Open Access Journal \\
\hline & ISSN No: 2456 - 6470 | www.ijtsrd.com | Volume - 2 | Issue - 5 \\
\hline
\end{tabular}

\title{
Experimental Study on Properties of Some Lesser Used Seasoned Timber Species in Myanmar
}

\author{
Hla Hla Htay, Pan Ei Phyu \\ Department of Civil Engineering, Yangon Technology University \\ Republic of Union of Myanmar, Yangon, Myanmar
}

\begin{abstract}
This study investigates the properties of four lesser used seasoned timber species in Myanmar: Inn (Dipterocarpus tuberculatus Roxb.), Kanyin (Dipterocarpus turbinatus), Thit-Sein (Terminalia bellirica Roxb.) and Yamane (Gmelina arborea Roxb.). The experiments are tested according to American Standard Methods of Testing Small Clear Specimens of Timber (ASTM D 143-09). The moisture content is examined in the kiln dried condition. The mechanical properties are done to measure the bending strength, compressive strength parallel to grain, compressive strength perpendicular to grain, and tensile strength perpendicular to grain and shear strength of each species of timber. In addition, the density and moisture content of timber are also measured for physical properties. Total 600 specimens (30 specimens for each test and species) are measured in this study. The results from experiments are also adjusted to $12 \%$ moisture content.
\end{abstract}

Keywords: Physical and mechanical properties of local seasoned timber species, ASTM D 143-09, Kiln dried condition, $12 \%$ moisture content

\section{INTRODUCTION}

Myanmar is a country with a long history of scientific forest management and possessing valuable natural forest resources. Over half of the country is covered with natural forests. So, forest products are the biggest sources of foreign income.

Wood is different from other construction materials because it grows naturally. Its mechanical properties largely depend on the species, age, location, climate

and humidity. Related to its physical properties, wood has different colors and odors. In addition, its unit weight, strength, density moisture content, and other characteristics are also different. The ability of wood to resist loads depends on a number of factors, including the type, direction, and duration of loading; ambient conditions of moisture content and temperature. The strength properties of wood are of importance in structural design. They are measure of the ability of wood to resist externally applied force which tends to alter its shape, size or result in any other deformation. Mechanical properties determine the applicability of wood in structure as well as many other uses where resistance to bending, compression, tension, shear and other effect of external force is required.

In Myanmar, more than 100 wood species are available to the prospective user. Efficient use of our nation's timber resource is a vital concern. Markets must be developed for lesser known timber species. The use of lesser known timber species is equally appropriate in civil and structural applications. The utilization of lesser used timber species in Myanmar will solve the crisis of demand and supply of timber.

The objective of this experimental study is to investigate the strength properties of timbers selected from four lesser used seasoned timber species in Myanmar.

\section{EXPERIMENTAL PROGRAMME \\ A. Materials}

In this study, four lesser used seasoned timber species are selected. They are Inn, Kanyin, Thit-Sein, and Yemane. 
B. Drying the Collected Timbers to an Average Moisture Content by Kiln Seasoning Method

The strength of timber increases with a decrease of moisture content below the fiber saturation point which is approximately $30 \%$ moisture content. Above this point, the strength of timber does not alter with any farther increase of moisture. To obtain comparative strength values of different timber species, it is necessary to test timber at above $30 \%$ moisture content which is green or saturated condition, or at standard moisture content below this value. The specimens are targeted for drying to an average moisture content of $12 \%$.
In kiln drying, higher temperatures and faster air circulation are used to increase drying rate considerably. Specific kiln schedules have been developed to control temperature and relative humidity in accordance with the moisture content within the wood, thus minimizing shrinkage-caused defects. Firstly, the collected timbers in this study are air-dried to average $100 \%$ moisture content for 120 hours before heating the kiln. Time-based kiln schedule is given in Table 1.

Table1. Time-Based Kiln Schedule for (3 in. thick) Collected Timbers, Dried to Average 12\% MC Day

\begin{tabular}{|c|c|c|c|c|}
\hline \multirow[t]{2}{*}{ Day } & \multirow{2}{*}{$\begin{array}{l}\text { Time } \\
\text { (hr) }\end{array}$} & \multicolumn{2}{|c|}{ Temperature $\left({ }^{\circ} \mathrm{C}\right)$} & \multirow{2}{*}{ Avg. Equilibrium MC } \\
\hline & & Dry-Bulb & Wet-Bullb & \\
\hline 1 & $0-24$ & $<50$ & $<45$ & 85 \\
\hline 2 & $24-48$ & 50 & 45 & 70 \\
\hline 3 & $48-72$ & 50 & 45 & 65 \\
\hline 4 & $72-96$ & 50 & 42 & 50 \\
\hline 5 & $96-120$ & 50 & 42 & 45 \\
\hline 6 & $120-144$ & 50 & 40 & 40 \\
\hline 7 & $144-168$ & 50 & $1 0 \longdiv { 4 3 }$ & 35.5 \\
\hline 8 & $168-192$ & 50 & 42 & 30 \\
\hline 9 & $192-216$ & 52 & 1145 & 25 \\
\hline 10 & $216-240$ & 53 & 43 & ad \\
\hline 11 & $240-264$ & 53 & 43 & 18.5 \\
\hline 12 & $264-288$ & $53 e 1$ & elo 4377 & 18.3 \\
\hline 13 & $288-312$ & 53 & 40 & 18 \\
\hline 14 & $312-336$ & 50 & $2 / 40$ & 16 \\
\hline 15 & $336-360$ & 50 & 45 & 15 \\
\hline 16 & $360-384$ & 50 & 40 & 14 \\
\hline 17 & $384-408$ & 53 & 47 & 13 \\
\hline 18 & $408-432$ & 54 & 48 & $\leq 12$ \\
\hline
\end{tabular}

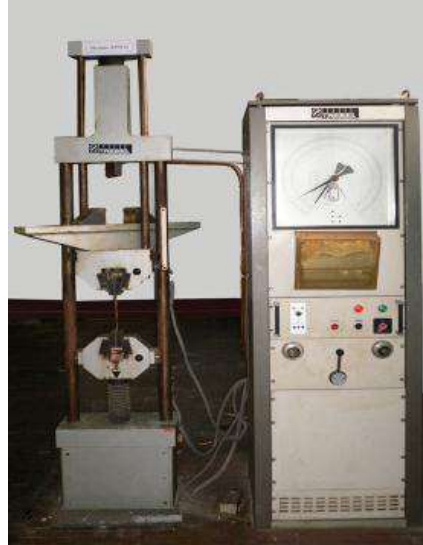

(a) Trebel Universal Testing Machine

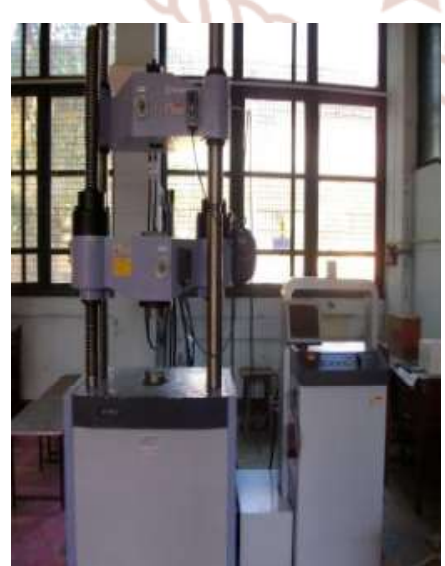

(b)Shimadzu Autograph Universal Testing Machine
Figure1. Testing machine
In this study the following strength properties were investigated:

1. Moisture content, specific gravity, density and bending strength

2. Compressive strength parallel to grain,

3. Compressive strength perpendicular to grain

4. Tensile strength perpendicular to grain and

5. Shear strength

1. Static bending strength test

The Trebel Universal Testing Machine (see Figure 1.(a)) set up with two supports and the four pointloading device as shown in the Figure 2. The species were broken on a four point's fixture shown in this figure. 
International Journal of Trend in Scientific Research and Development (IJTSRD) ISSN: 2456-6470

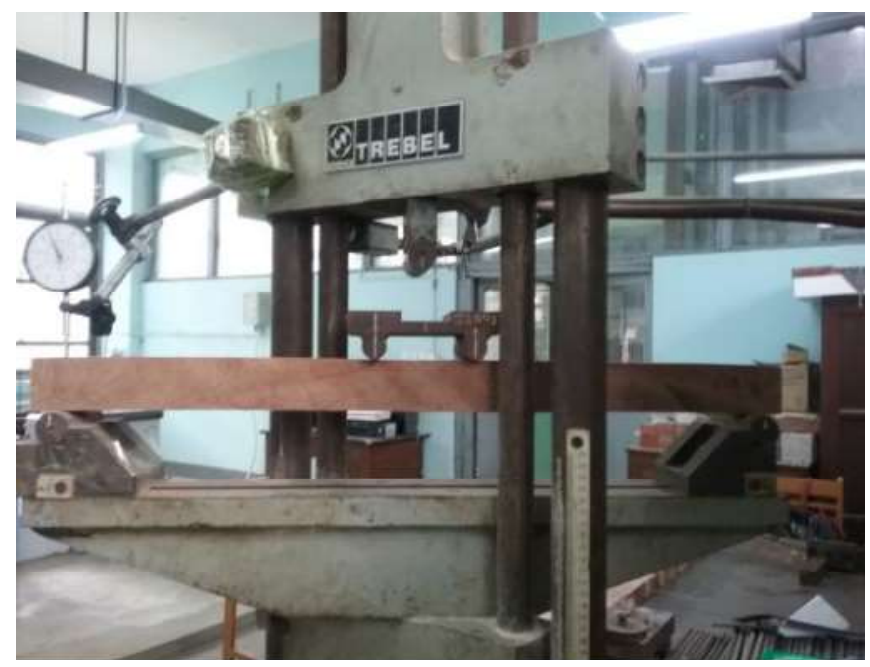

(a) Preparation specimen (2in. $\times 2$ in. $\times 30$ in., span length $=28$ in.)

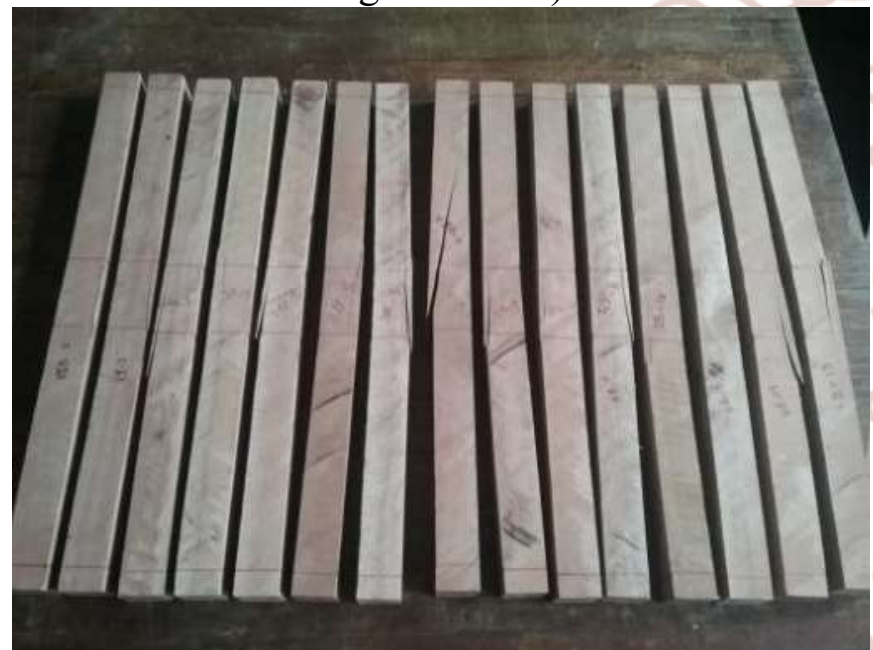

(b)Failure specimens

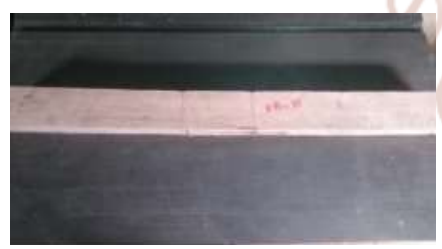

(c) Simple grain tension tension failure (Kanyin)

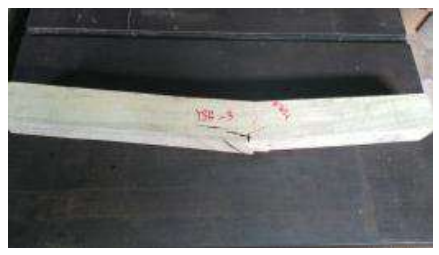

(e) Splintering tension failure (Yemane)

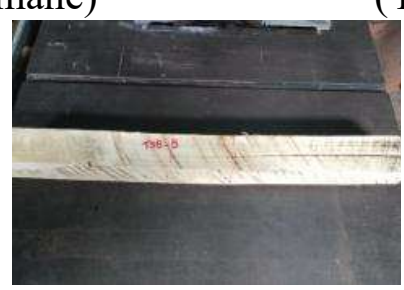

(f) Brash tension failure (Yemane)

\section{(d) Cross grain}

failure (Kanyin)

2. Compressive strength parallel to grain test In this test, the compressive strength is measured by applying the force parallel to the grain, as shown in Figure 3.

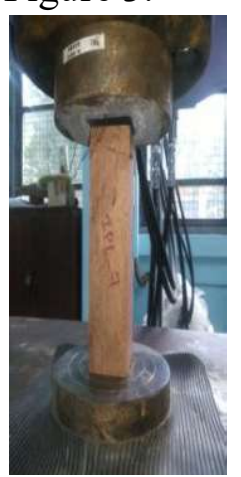

(a)Expermental set-up

( 2 in. $\times 2$ in. $\times 8$ in.)

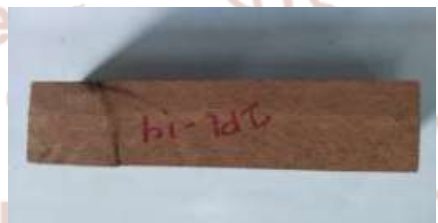

(c) Crushing failure (Inn)

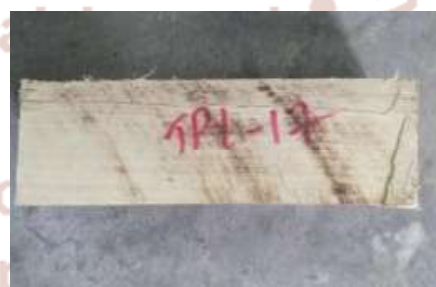

(e)Splitting failure

(Thit-Sein)

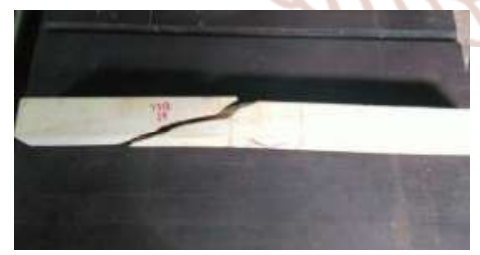

(g)Horizontal shear failure (Thit-Sein)

Figure 2. Static bending test parallel to grain failure (Inn) as shown in Figure 4.

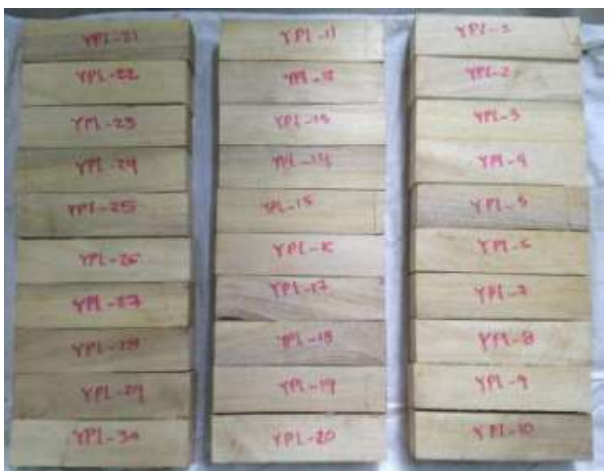

(b) Failure specimens

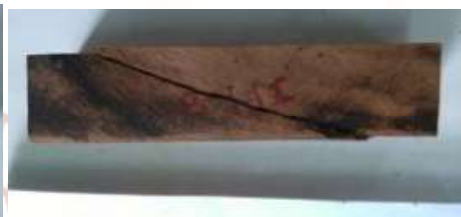

(d)Shearing failure(Inn)

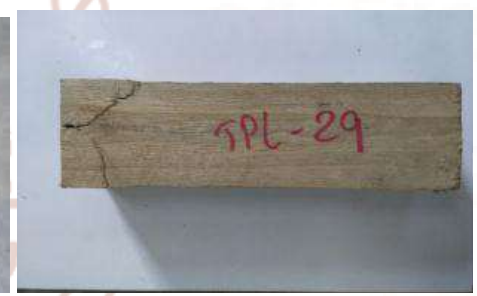

(f) Wedge split failure (Thit-Sein)

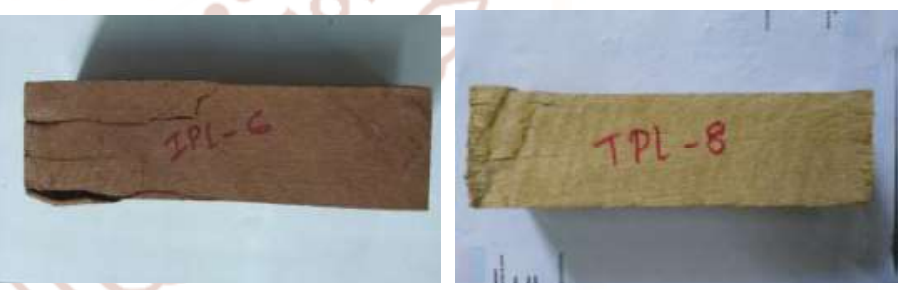

(g) Compression and shearing (h)End-rolling failure

(Inn)

Figure3. Compression parallel to grain test

3. Compressive strength perpendicular to grain test This test is a measure of the bearing strength values of member subjected to applying force across the grain, 


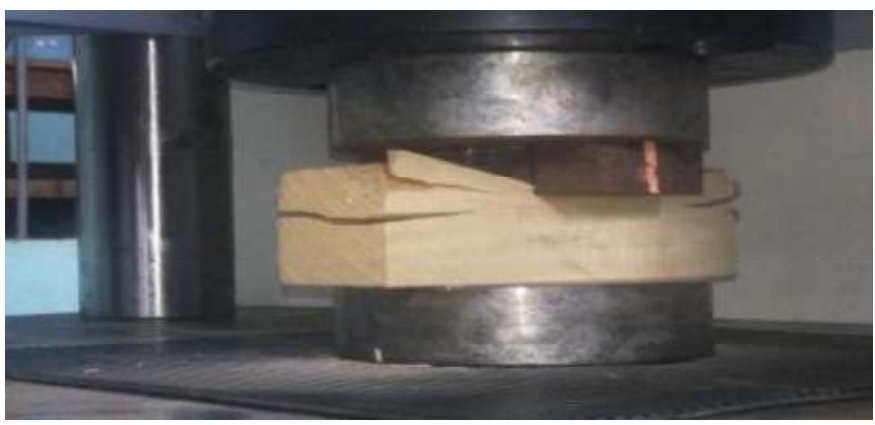

(a) Experimental set-up of specimen ( 2 in. $\times 2$ in. $\times 6$ in.)

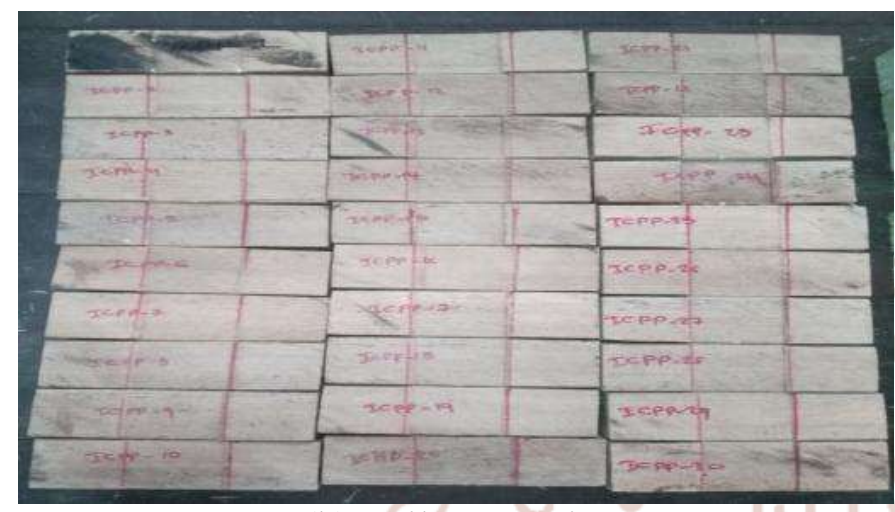

(b) Failure specimens

Figure4. Compression perpendicular to grain test

Tensile strength perpendicular to the grain is a measure of the resistance of wood to forces acting across the grain which then to cause splits or cleavage, as shown in Figure 5.

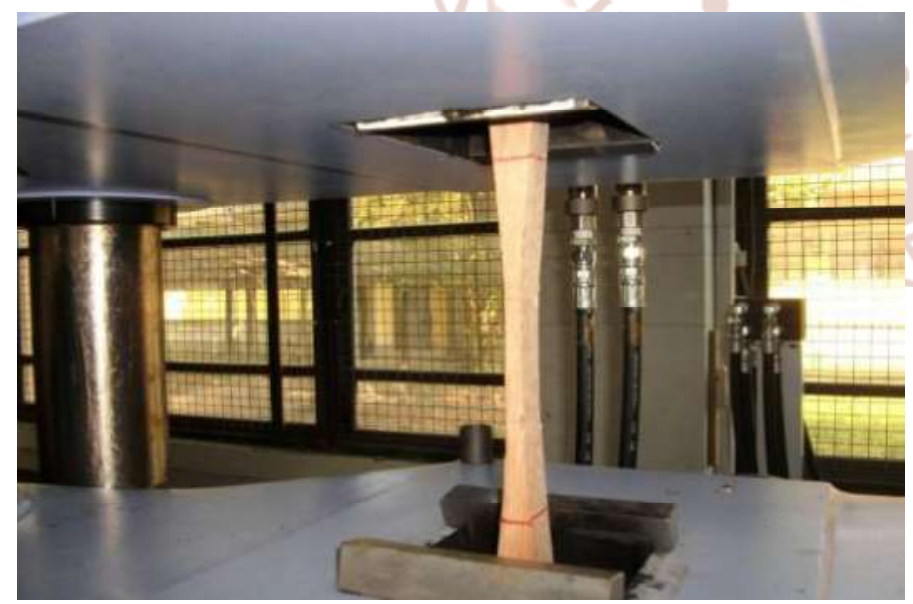

(a) Experimental set-up of specimen (18 in. length cross section 1in. $\times 1$ in. at the end, 1 in. $\times 3 / 8$ in. in the middle)

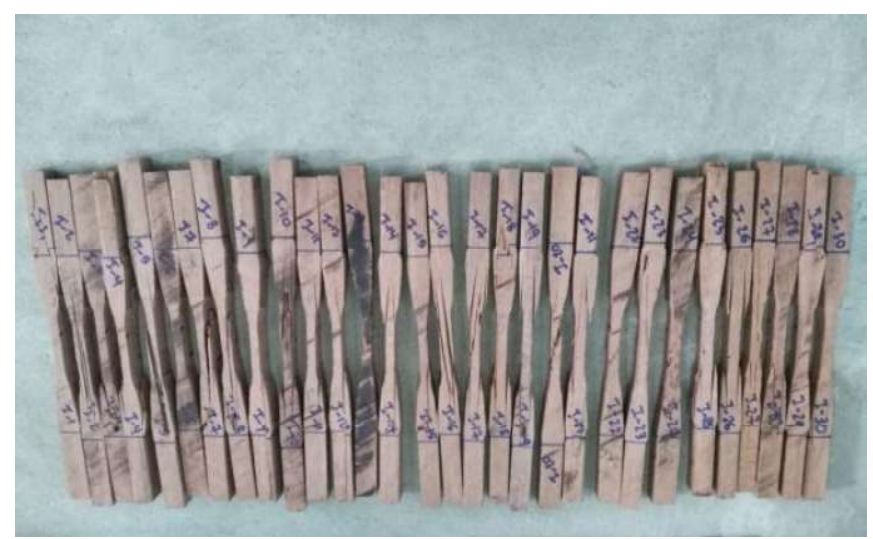

(b)Failure specimens

Figure 5. Tension Parallel to Grain Test

5. Shear parallel to grain test

This test is the measure of the total load required to shear the specimen in two. The shear strength is the ability to resist internal slipping of one part upon another along the grain or across the grain. Figure. 6 represents shear test.

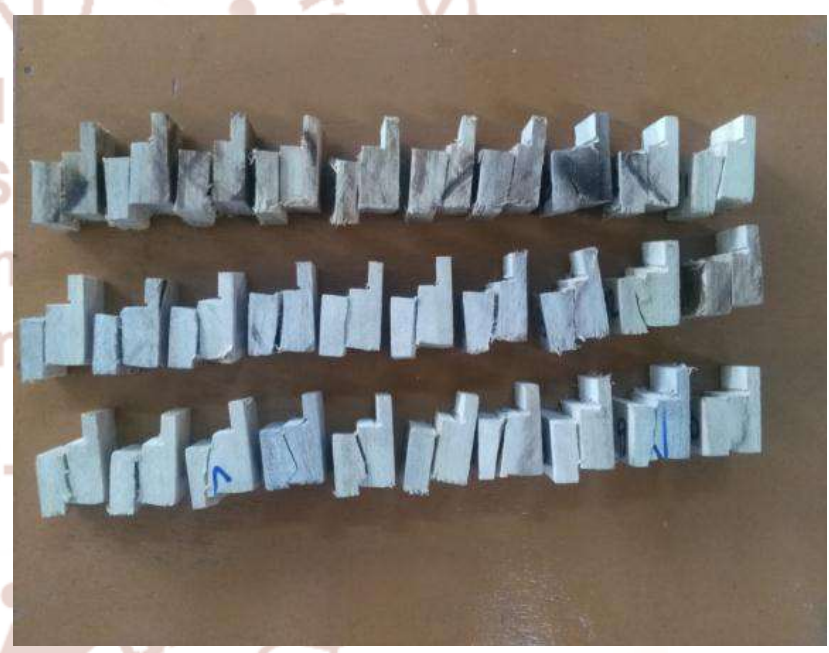

(a) Experimental Set-up of specimen ( 2 in. $\times 2$ in. $\times 2$

$1 / 2 \mathrm{in}$. is notched to produce failure on $2 \mathrm{in} . \times 2 \mathrm{in}$.)

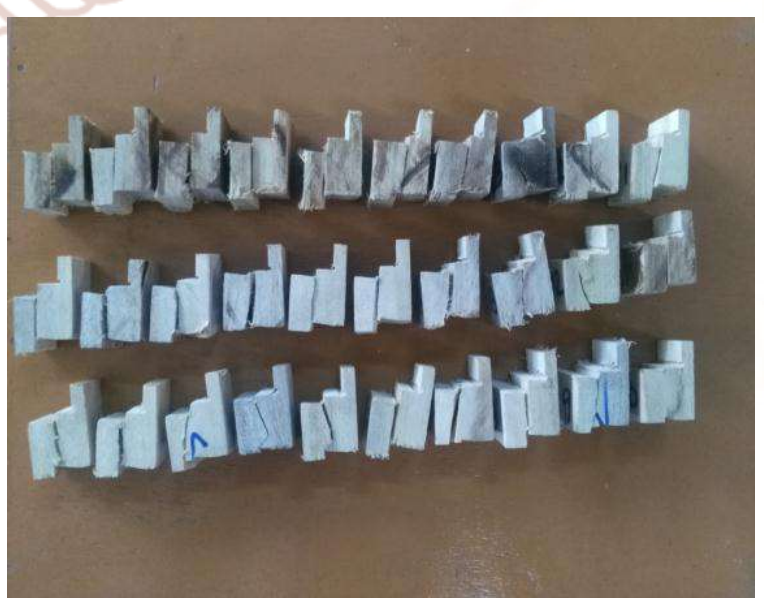

(c) Failure Specimens

Figure6. Shear parallel to grain test 


\section{TEST RESULTS AND DISCUSSIONS}

In this study, the strength properties which are commonly used in design purposes are measured including bending, compression parallel and perpendicular to the grain, tension perpendicular to the grain, and shear parallel to the grain for four species. For each test and species 30 specimens were measured at $12 \% \mathrm{MC}$, according to ASTM D 143-09.

Figure 7 and 8 represent the fibre stress in bending, modulus of rupture and modulus of elasticity, respectively. The compressive stresses parallel and perpendicular to grain were as shown in Figure.9 and 10, respectively. Figure.11 and 12 represent the tension and shear strength parallel to grain, respectively.

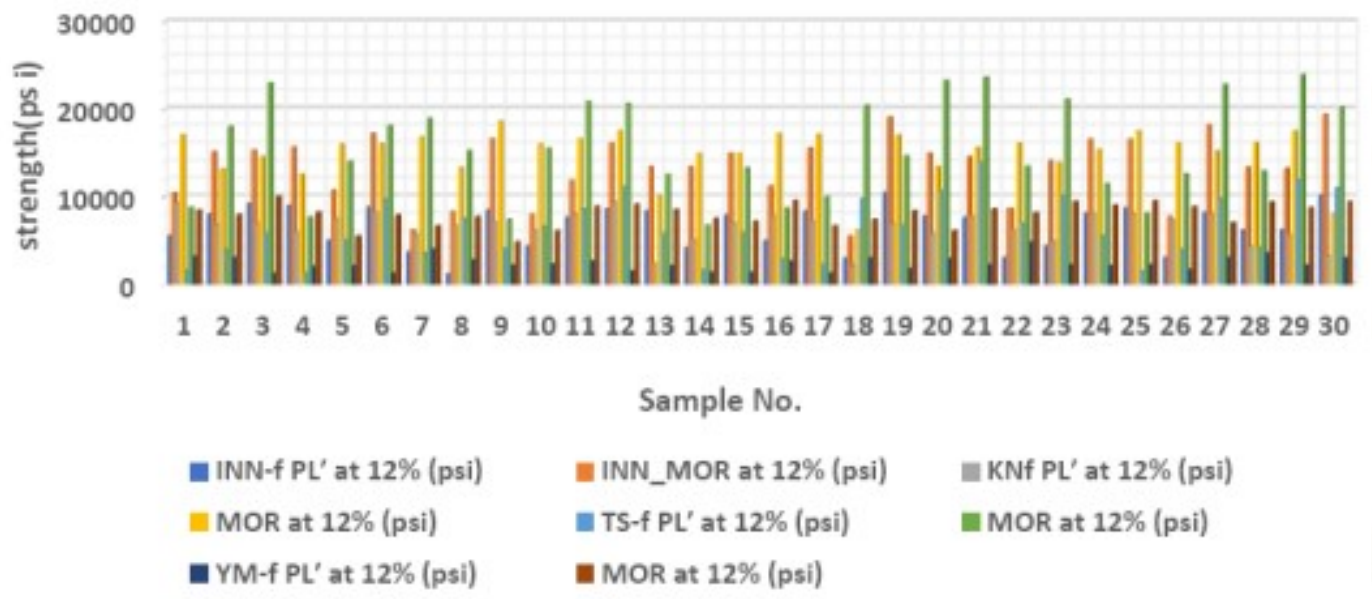

Figure 7. Comparison of PLf $\square$ and MOR for Inn, Kanyin, Thit-Sein and Yemane at $12 \%$ MC
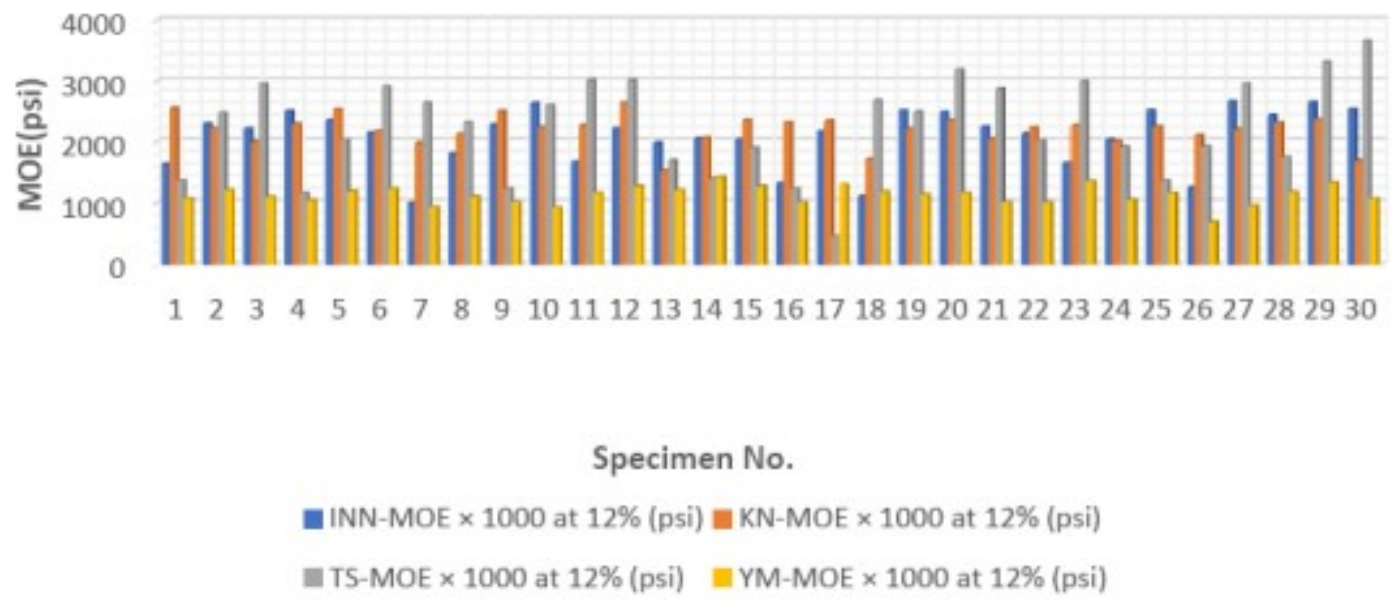

Figure 8. Comparison of MOE for Inn, Kanyin, Thit-Sein and Ymane at 12\% MC

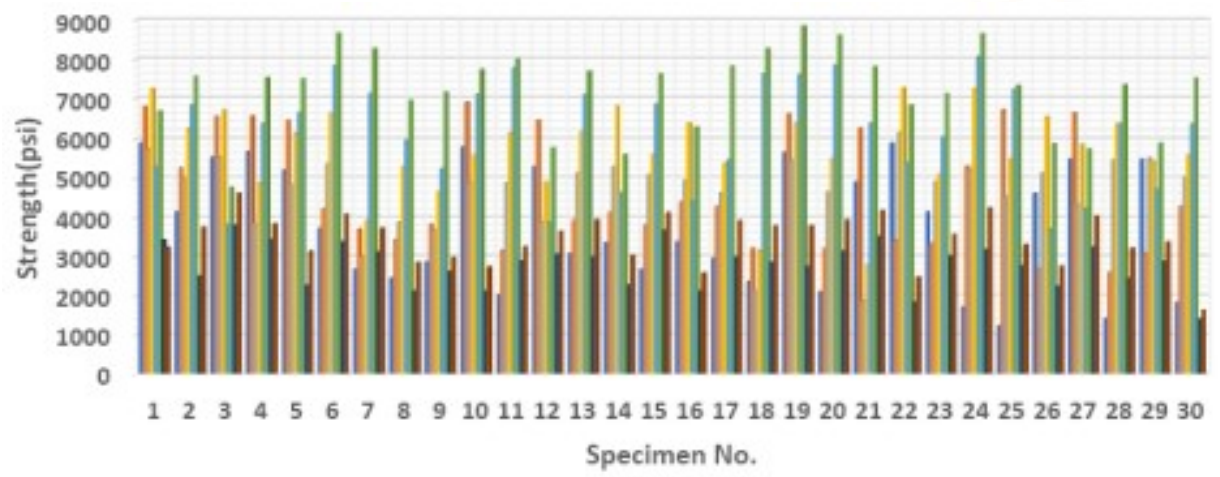

EINN-f $\mathrm{f} / /$ at $12 \%$ (psi) $=\mid \mathrm{INN}_{-} \mathrm{fc} / /$ at $12 \%$ (psi $=\mathrm{KN}-\mathrm{f}^{\prime} \mathrm{c} / /$ at $12 \%$ (psi) $=\mathrm{KN}-\mathrm{fc} / /$ at $12 \%$ (psi

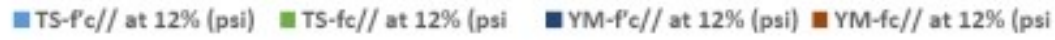

Figure 9. Comparison of $\mathrm{f}^{\prime} \mathrm{c} / /$ and fc// for Inn, Kanyin, Thit-Sein and Yemane at 12\% MC 


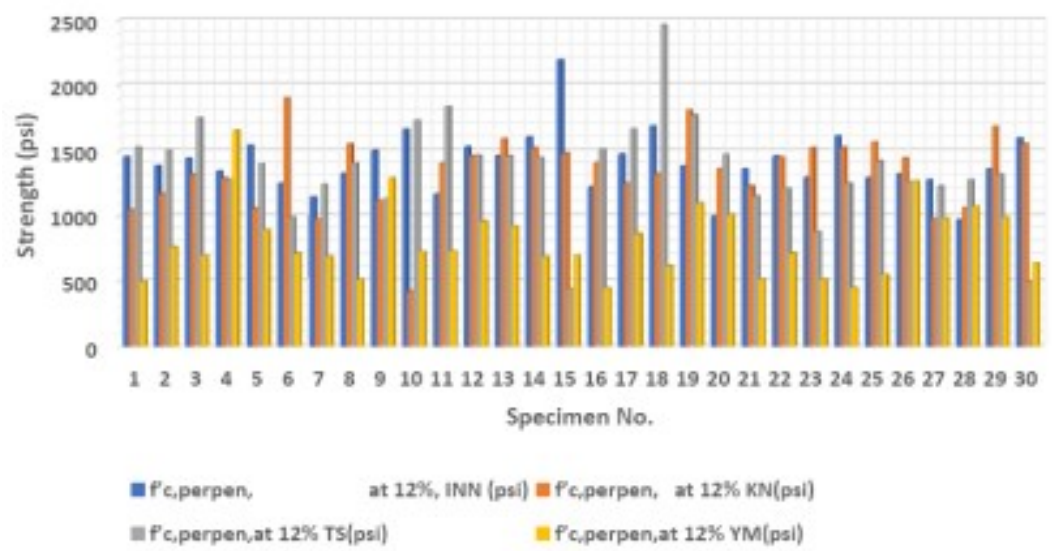

Figure 10. Comparison of $\perp \square$,cf for Inn, Kanyin, Thit-Sein and Yemane at 12\% MC

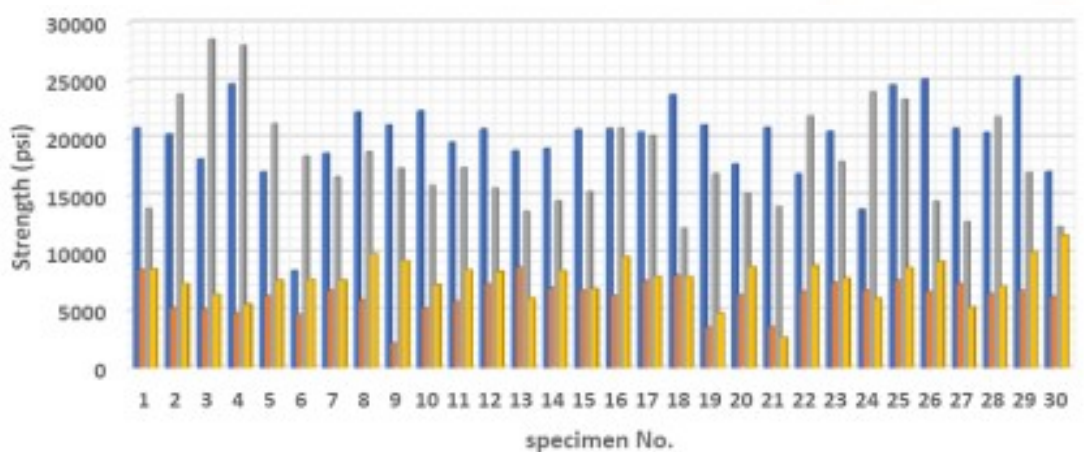

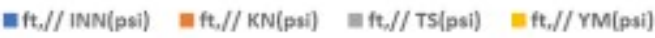

Figure 11. Comparison of Maximum Tensile Stress ft,// for Inn, Kanyin, Thit-Sein and Yemane at 12\% MC

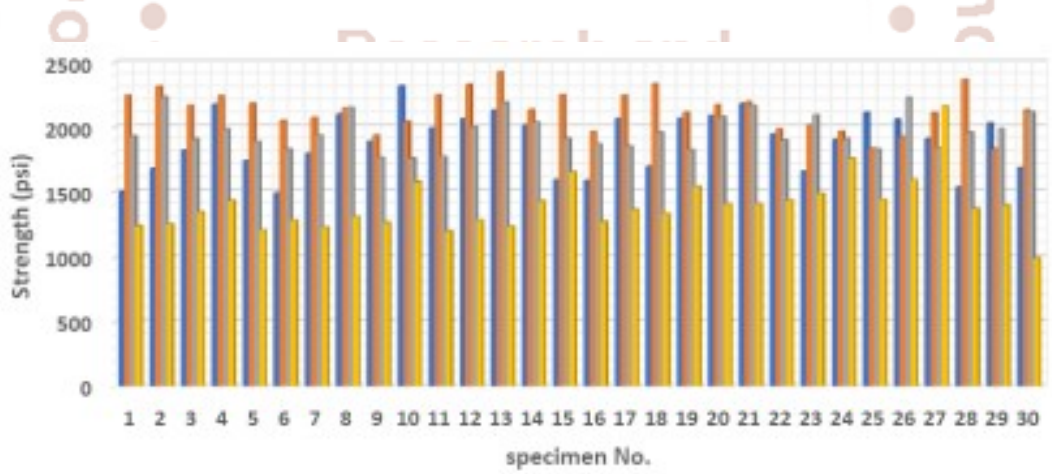

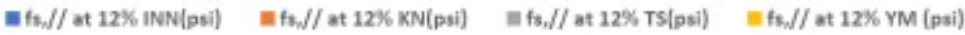

Figure 12. Comparison of Maximum Shearing Stress fs,// for Inn, Kanyin, Thit-Sein and Yemane at 12\% M

From the experiments mean strength values of each property and species at $12 \% \mathrm{MC}$ are listed in Table 2 . The allowable strength of each property is obtained by multiplying the respective factor of safety given in Table 3 to the mean strength shown in Table 2. It is listed in Table 5 and as shown in Figure 13,14 and 15 respectively. The allowable density of each species is listed in Table 4.

Table 2. Strength for Four Timber Species at $12 \% \mathrm{MC}$

\begin{tabular}{|c|c|c|c|c|c|c|c|c|}
\hline $\begin{array}{l}\text { Traditional } \\
\text { Name }\end{array}$ & (psi) & $\begin{array}{l}\mathrm{MOR} \\
\text { (psi) }\end{array}$ & $\begin{array}{l}\text { MOEx } 103 \\
\text { (psi) }\end{array}$ & $(\mathrm{psi}) / /, \mathrm{cfl}$ & $(\mathrm{psi}) / /, \mathrm{cf}$ & (psi) & $\begin{array}{l}\text { ft, } / / \\
\text { (psi) }\end{array}$ & $\begin{array}{l}\mathrm{fs} / \mathrm{l} \\
\text { (psi) }\end{array}$ \\
\hline Inn & 6696.73 & 13393.61 & 2085.51 & 3620.12 & 4710.43 & 1410.93 & 20065.11 & 1892.04 \\
\hline Kanyin & 6548.81 & 14985.87 & 2199.18 & 4676.33 & 5715.85 & 1350.47 & 18201.78 & 2129.50 \\
\hline Thit-Sein & 6452.98 & 15577.67 & 2251.09 & 6134.1 & 7252.4 & 1366.64 & 18090.02 & 1961.02 \\
\hline Yemane & 2409.78 & 8043.7 & 1122.53 & 2805.6 & 3463.12 & 806.0 & 7712.11 & 1398.38 \\
\hline
\end{tabular}


International Journal of Trend in Scientific Research and Development (IJTSRD) ISSN: 2456-6470

Table 3. Safety Factors for Each Mechanical Property

\begin{tabular}{|c|c|c|c|c|}
\hline \multirow{2}{*}{$\begin{array}{c}\text { Strength } \\
(\mathrm{psi})\end{array}$} & \multicolumn{2}{|c|}{ Strength Ratio Associated with } & \multirow{2}{*}{$\begin{array}{c}\text { Adjusted } \\
\text { Safety Factor }\end{array}$} \\
\cline { 2 - 5 } & Slope of Grain & Knot & Checks and Splits & $1 / 6.3$ \\
\hline Bending $\mathrm{f}_{\mathrm{PL}}^{\prime}$ & 0.61 & 0.6 & - & $1 / 1.18$ \\
\hline $\begin{array}{c}\text { Modulus of } \\
\text { Elasticity(MOE) }\end{array}$ & \multicolumn{3}{|c|}{0.80 for $\mathrm{S}_{\mathrm{b}}<0.44$} & $1 / 4.73$ \\
\hline $\begin{array}{c}\text { Compression } \\
\text { parallel } \mathrm{f}_{\mathrm{c}, / /}^{\prime}, \mathrm{f}_{\mathrm{c}, / /}\end{array}$ & 0.74 & 0.6 & - & $1 / 1.67$ \\
\hline $\begin{array}{c}\text { Compression } \\
\text { perpendicular } \mathrm{f}_{\mathrm{c}, \perp}^{\prime}\end{array}$ & - & - & - & $1 / 11.43$ \\
\hline Tension parallel $\mathrm{f}_{\mathrm{t},} / /$ & \multicolumn{3}{|c|}{$0.55 \times 1$ for $\mathrm{S}_{\mathrm{b}}\left(55 \%\right.$ of $\left.\mathrm{S}_{\mathrm{b}}\right)$} & $1 / 4.6$ \\
\hline \begin{tabular}{c} 
Shear parallel $\mathrm{f}_{\mathrm{s}, / /}$ \\
\hline
\end{tabular}
\end{tabular}

$\overrightarrow{\mathrm{W} h e r e}, \overline{\mathrm{Sb}}=\dot{b e n d i n g}$ strength ratio

Table 4. Allowable Density for Four Timber Species at 12\%MC

\begin{tabular}{|l|l|l|}
\hline Traditional Name & Botanical Name & Density (lb/ft3) \\
\hline Inn & Dipterocarpus tuberculatus Roxb. & $53-57$ \\
\hline Kanyin & Dipterocarpus turbinatus Roxb. & $52-59$ \\
\hline Thit-Sein & Terminalia bellirica Roxb. & $48-58$ \\
\hline Yemane & Gmelina arborea Roxb.), & $30-36$ \\
\hline
\end{tabular}

Table 5. Allowable Strength for Four Timber Species at 12\%MC

\begin{tabular}{|c|c|c|c|c|c|c|c|c|}
\hline $\begin{array}{l}\text { Traditional } \\
\text { Name }\end{array}$ & (psi) & $\begin{array}{l}\text { MOR } \\
\text { (psi) }\end{array}$ & $\begin{array}{l}\text { MOEx103 } \\
\text { (psi) }\end{array}$ & (psi) & (psi) & (psi) & $\begin{array}{l}\mathrm{fit}, / / \\
\text { (psi) }\end{array}$ & $\begin{array}{l}\text { fs, // } \\
\text { (psi) }\end{array}$ \\
\hline Inn & 1062.97 & 13393.61 & 1767.38 & 765.35 & 995.86 & 844.87 & 1755.48 & 411.31 \\
\hline Kanyin & 10 & 14985.87 & 1863.71 & 988.65 & 1208.42 & 808.66 & 1592.46 & 462.93 \\
\hline Thit-Sein & 1024.28 & 15577.67 & 1907.70 & 1296.84 & 1533.28 & 818.35 & 1582.68 & 426.31 \\
\hline Yemane & 382.51 & 8043.7 & 951.30 & 593.15 & 732.16 & 482.64 & 674.73 & 303.99 \\
\hline
\end{tabular}

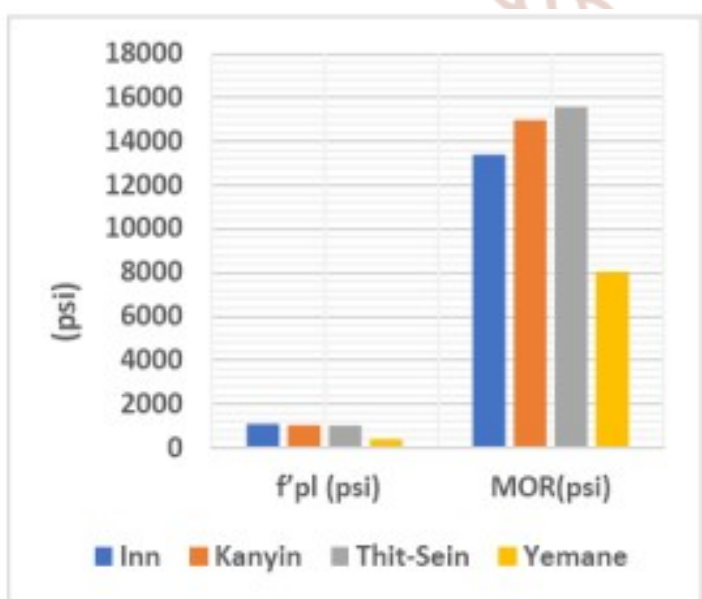

Figure 13. Comparison of Allowable ( PL f $\square$ ), (MOR) for Inn, Kanyin, Thit-Sein and Yemane at $12 \% \mathrm{MC}$

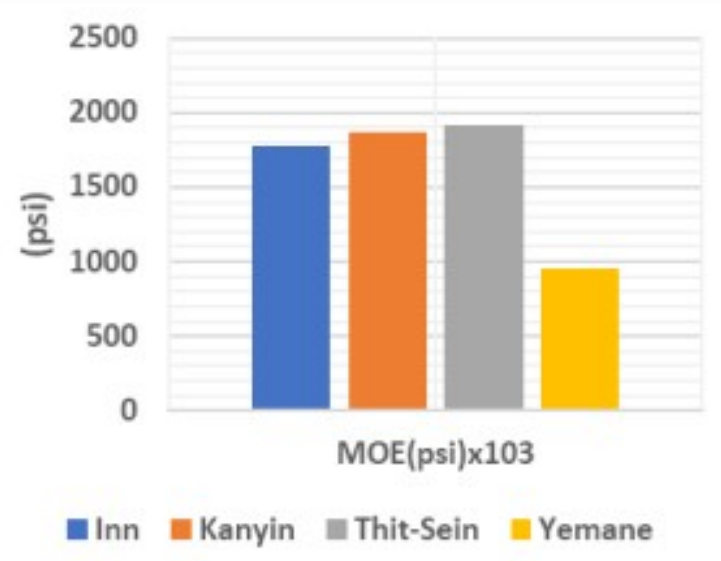

Figure 14. Comparison of Allowable (MOE) for Inn, Kanyin, Thit-Sein and Yemane at 12\% MC 


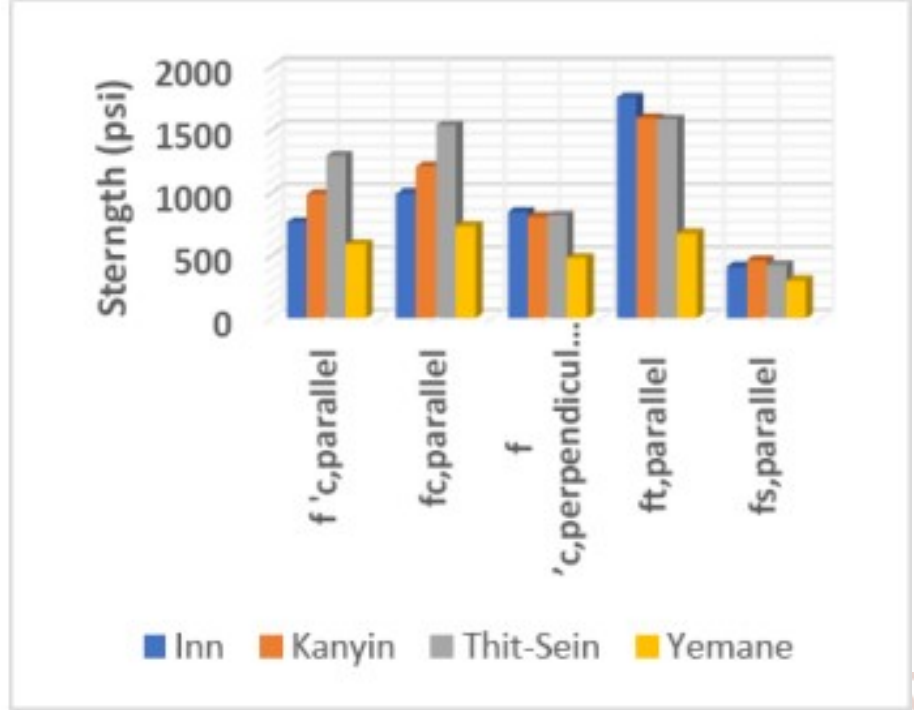

Figure15. Comparison of Allowable Values in $\mathrm{fc} / /$, $\mathrm{f}^{\prime} \mathrm{c} / /, \infty{ }^{\prime}, \mathrm{c} \mathrm{f}, \mathrm{ft}, / /$ and $\mathrm{fs}, / /$ for Inn, Kanyin, Thit-Sein and Yemane at $12 \% \mathrm{MC}$

\section{CONCLUSIONS}

Based on results of this study, it can be concluded that:

1. The unit weight of lesser used seasoned timber species is different from one species to another. It can be observed that as the density increases, the various strength properties also increase.

2. For the density, Kanyin has greatest and Yemane has lowest.

3. Inn has greatest value and Yemane has lowest value for bending strength, compressive strength perpendicular to grain, and tensile strength parallel to grain.

4. In compressive strength parallel to grain, ThitSein has greatest and Yemane has lowest.

5. In shear strength, Kanyin has the highest and Yemane has the lowest.
6. Yemane has the lowest strength for all tests and therefore it should not be used among these four lesser used seasoned species.

7. Although Thit-Sein has the high strength for almost all tests, chemical treatment should be added to this species for usage due to its nature of likely to be attacked by insets.

\section{ACKNOWLEDGEMENTS}

The author is deeply grateful her student Pan Ei Phyu for her support and effort to writing this paper.

\section{REFERENCES}

1. Anon. 1983. ASTM Standard Methods of Testing Small Clear Specimens of Timber D 143-09.

2. Anon. 1957. British Standard Methods of Testing Small Clear Specimens of Timber. B.S. 373: 1957. British Standard Institution.

3. Yale H. 1958.Wood Structural Design Data, Vol.1., Third Edition

4. Anon. 1999. Wood Handbook - Wood as an Engineering Material. FPL-GTR- 113. Madison, WI: United States Department of Agriculture, Forest Service, Forest Products Laboratory.

5. Desch, H. E. 1973. Timber: Its Structure and Properties. 5th. ed. Macmillan Press Ltd.

6. MK Mohamad Omar\& Mohd Jamil., 2012. "Use Of Timber In Engineering" Timber Technology Bulletin 50: 139-258. Negi, S.S., I. F. S. 1997. Wood Science and Technology. Applied forestry series No. 2, Dehra Dun, India.

7. Record, S. J., 1914. The Mechanical Properties of Wood. New York 